\title{
The Ponto-Caspian mysid Paramysis lacustris (Czerniavsky, 1882) has colonized the Middle Danube
}

\author{
Péter Borza ${ }^{1,2, *}$, Krisztián Kovács ${ }^{3}$, Alexandra György ${ }^{4}$, Júlia Katalin Török ${ }^{4}$ and Ádám Egri ${ }^{2}$ \\ ${ }^{1}$ GINOP Sustainable Ecosystems Group, MTA Centre for Ecological Research, Klebelsberg Kuno utca 3, 8237 Tihany, Hungary \\ 2 Danube Research Institute, MTA Centre for Ecological Research, Karolina út 29-31, 1113 Budapest, Hungary \\ ${ }^{3}$ Laboratory for Environmental Protection, Government Office of Győr-Moson-Sopron, Török Ignác utca 68, 9028 Győr, Hungary \\ ${ }^{4}$ Department of Systematic Zoology and Ecology, Eötvös Loránd University, Pázmány Péter sétány 1/C, 1117 Budapest, Hungary
}

\begin{abstract}
In 2017, the mysid Paramysis lacustris (Czerniavsky, 1882) was found for the first time in the Hungarian Danube section, representing the first psammo-pelophilous Ponto-Caspian peracarid colonizing the Middle Danube. In 2018, a brief survey focusing on this species revealed its presence in a more than 500-km-long river section spanning from Austria (Vienna, river km 1926) to Croatia (Batina, river $\mathrm{km}$ 1425). The largest populations of $P$. lacustris might be formed in reservoirs and slow-flowing stretches, where the appearance of the species might imply a considerable impact in connection with its zooplanktivorous feeding and important role in the diet of fish. Similar to all the other Ponto-Caspian peracarids that have crossed the Middle Danube, $P$. lacustris can reasonably be expected to continue its spread toward Western Europe in the future.
\end{abstract}

Keywords: range expansion / Crustacea / Mysida / psammo-pelophilous / jump dispersal

In recent decades, several Ponto-Caspian peracarid crustaceans (i.e., amphipods, isopods, and mysids) have expanded their ranges in Central and Western Europe, in which the River Danube has played a pivotal role as part of the "southern invasion corridor" (the Danube-Main-Rhine system; Bij de Vaate et al., 2002). Crossing the comparatively unregulated Middle Danube has been identified as the key step of the invasion process; all species that have appeared in the German or Austrian section (Upper Danube) so far have been able to colonize additional Western European catchments (Borza et al., 2015). All these species show affinity to hard substrates (lithophilous), although the majority of the PontoCaspian peracarid fauna prefer sandy-muddy habitats (psammo-pelophilous; Borza et al., 2017). In the present publication we report on the range expansion of $P$. lacustris (Fig. 1), the first psammo-pelophilous Ponto-Caspian peracarid colonizing the Middle Danube.

$P$. lacustris is native to the Black, Azov, and Caspian Seas as well as to the lower sections of rivers draining into them (Audzijonyte et al., 2015). In the Soviet era, it was introduced into several waters outside its native range, including lakes and reservoirs in Lithuania, which allowed its expansion in the Baltic Sea basin (Zettler, 2015; Audzijonyte et al., 2017). In the River Danube, the native range of the species was restricted to the lower $\sim 600$ river km (Wittmann, 2007); however,

\footnotetext{
*Corresponding author: borza.peter@okologia.mta.hu
}

during the latest international survey on the river ("Joint Danube Survey 3," 2013), its upstream distributional limit corresponded approximately to the confluence with the River Tisza (riverkm $\sim 1200$, Fig. 2; Borza et al., 2015) in accordance with its previous range expansion in this tributary (Borza and Boda, 2013).

P. lacustris was first detected in the Hungarian Danube section in the summer of 2017. By that time it had already colonized a large area, since it was found in the most upstream part (Szigetköz, river km 1850) during the regular biomonitoring, as well as in Budapest in the course of an ongoing thesis project (river km 1642; Tab. 1, Fig. 2). In 2018, a brief survey focusing on this species (daytime sampling using a hand net with $500 \mu \mathrm{m}$ mesh size) revealed its presence in a more than $500 \mathrm{~km}$-long river section spanning from Austria to Croatia. The most upstream occurrence was recorded in the impounded river section of the Freudenau dam in Vienna (river km 1926). The species has already entered the major flood-protected sidearms of the Middle Danube (the Slovakian Malý Dunaj, and the Hungarian Mosoni and Ráckevei-Sorokári Danubearms; Tab. 1). Our records represent the first occurrence of the species for the Slovakian and Croatian fauna, as well as the first indication of a self-sustaining population in Austria (cf. Wittmann, 2007).

Although the species is capable of active upstream spread under certain conditions, as indicated by records in Lithuanian rivers (Arbačiauskas et al., 2011), we consider this mechanism 


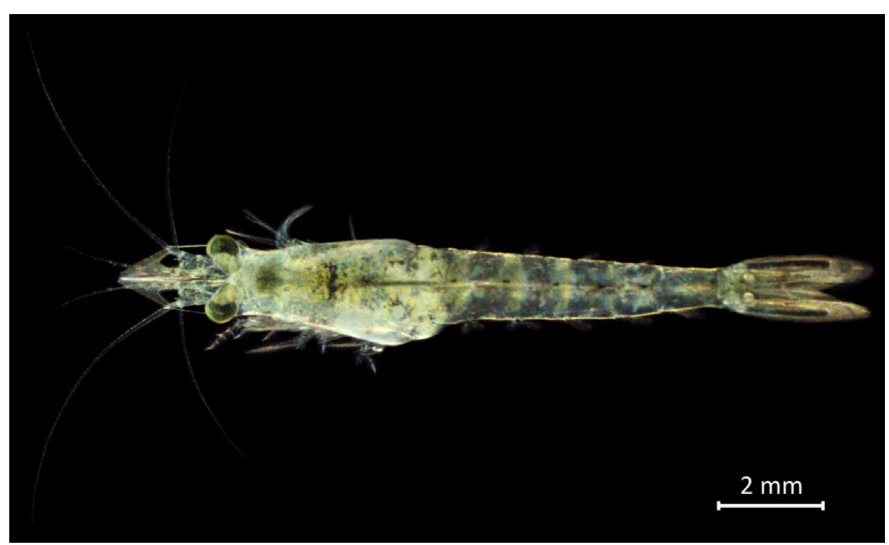

Fig. 1. Adult female specimen of P. lacustris.

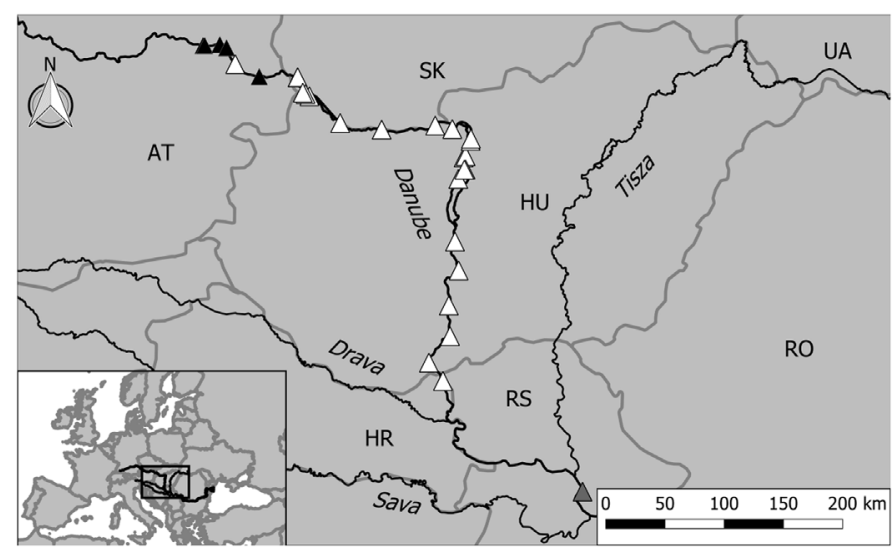

Fig. 2. Sampling sites in the Middle Danube. White triangles: $P$. lacustris present; black triangles: P. lacustris absent; grey triangle: the most upstream occurrence of $P$. lacustris during the Joint Danube Survey 3 (Borza et al., 2015). Country codes in addition to Table 1: RO: Romania, UA: Ukraine, RS: Serbia.

Table 1. Records of mysids in the Middle Danube (ordered by river km-s). PL: Paramysis lacustris (Czerniavsky, 1882), KW: Katamysis warpachowskyi G.O. Sars, 1893, LB: Limnomysis benedeni Czerniavsky, 1882. River km-s of sampling points in sidearms represent the nearest point in the main channel. Country codes: AT: Austria, SK: Slovakia, HU: Hungary, HR: Croatia. Since the samples were collected during the day, they cannot be regarded as representative for the nocturnally active Hemimysis anomala (G.O. Sars, 1907). The sampling was not quantitative; therefore, the numbers of collected specimens serve as only a rough indication of the relative densities of the three mysid species.

\begin{tabular}{|c|c|c|c|c|c|c|c|c|}
\hline Date & River km & Country & Location & Geographic coordinates & Habitat & PL & KW & LB \\
\hline 17.09 .2018 & 1963 & $\mathrm{AT}$ & Tulln 1 & $48^{\circ} 20^{\prime} 13.30^{\prime \prime} \mathrm{N} 16^{\circ} 03^{\prime} 34.70^{\prime \prime} \mathrm{E}$ & Rip-rap & & 6 & 14 \\
\hline 17.09.2018 & 1962 & $\mathrm{AT}$ & Tulln 2 & $48^{\circ} 20^{\prime} 15.53^{\prime \prime} \mathrm{N} 16^{\circ} 04^{\prime} 42.07^{\prime \prime} \mathrm{E}$ & Mud, gravel, algae & & 9 & \\
\hline 17.09.2018 & 1949 & AT & Greifenstein & $48^{\circ} 21^{\prime} 01.15^{\prime \prime} \mathrm{N} 16^{\circ} 14^{\prime} 59.97^{\prime \prime} \mathrm{E}$ & Mud & & 49 & 5 \\
\hline 17.09 .2018 & 1942 & AT & Klosterneuburg & $48^{\circ} 19^{\prime} 41.88^{\prime \prime} \mathrm{N} 16^{\circ} 19^{\prime} 43.43^{\prime \prime} \mathrm{E}$ & Sand, gravel & & 13 & 1 \\
\hline 17.09.2018 & 1926 & AT & Vienna, Alte Donau & $48^{\circ} 12^{\prime} 49.30^{\prime \prime} \mathrm{N} 16^{\circ} 26^{\prime} 15.45^{\prime \prime} \mathrm{E}$ & Stones, macrophytes & & 2 & 22 \\
\hline 17.09.2018 & 1926 & AT & Vienna, Danube main arm & $48^{\circ} 12^{\prime} 29.01^{\prime \prime} \mathrm{N} 16^{\circ} 26^{\prime} 10.52^{\prime \prime} \mathrm{E}$ & Rip-rap, mud & 47 & 5 & 4 \\
\hline 17.09.2018 & 1902 & AT & Haslau & $48^{\circ} 07^{\prime} 18.57^{\prime \prime} \mathrm{N} 16^{\circ} 42^{\prime} 55.58^{\prime \prime} \mathrm{E}$ & Gravel & & & 0 \\
\hline 17.09.2018 & 1866 & SK & Bratislava, Danube inlet & $48^{\circ} 07^{\prime} 39.24^{\prime \prime} \mathrm{N} 17^{\circ} 09^{\prime} 02.26^{\prime \prime} \mathrm{E}$ & Mud & 23 & 1 & \\
\hline 17.09.2018 & 1866 & SK & Bratislava, Malý Dunaj & $48^{\circ} 07^{\prime} 43.43^{\prime \prime} \mathrm{N} 17^{\circ} 09^{\prime} 07.31^{\prime \prime} \mathrm{E}$ & $\begin{array}{l}\text { Mud, riparian } \\
\text { vegetation }\end{array}$ & 9 & 3 & 12 \\
\hline 22.08 .2017 & 1850 & HU & Rajka, Mosoni-Danube & $48^{\circ} 00^{\prime} 45.84^{\prime \prime} \mathrm{N} 17^{\circ} 12^{\prime} 59.47^{\prime \prime} \mathrm{E}$ & Gravel & 2 & & 2 \\
\hline 22.08 .2017 & 1848 & $\mathrm{HU}$ & Rajka & $48^{\circ} 00^{\prime} 14.88^{\prime \prime} \mathrm{N} 17^{\circ} 14^{\prime} 53.62^{\prime \prime} \mathrm{E}$ & Gravel, mud & 6 & & 19 \\
\hline 22.08 .2017 & 1845 & HU & Dunakiliti, Helenai-Danube arm & $47^{\circ} 59^{\prime} 16.34^{\prime \prime} \mathrm{N} 17^{\circ} 17^{\prime} 35.44^{\prime \prime} \mathrm{E}$ & Rip-rap, mud & 6 & & 16 \\
\hline 04.04 .2018 & 1806 & $\mathrm{HU}$ & Vámosszabadi (Győrzámoly) & $47^{\circ} 47^{\prime} 30.92^{\prime \prime} \mathrm{N} 17^{\circ} 39^{\prime} 03.69^{\prime \prime} \mathrm{E}$ & Gravel & 3 & & 7 \\
\hline 15.05 .2018 & 1806 & $\mathrm{HU}$ & Vámosszabadi (Győrzámoly) & $47^{\circ} 47^{\prime} 30.92^{\prime \prime} \mathrm{N} 17^{\circ} 39^{\prime} 03.69^{\prime \prime} \mathrm{E}$ & Gravel & 49 & 9 & 10 \\
\hline 31.08 .2017 & 1768 & $\mathrm{HU}$ & Komárom & $47^{\circ} 45^{\prime} 03.93^{\prime \prime} \mathrm{N} 18^{\circ} 07^{\prime} 14.93^{\prime \prime} \mathrm{E}$ & Gravel, mud & 8 & & 1 \\
\hline 30.09 .2018 & 1719 & SK & Štúrovo & $47^{\circ} 47^{\prime} 25.65^{\prime \prime} \mathrm{N} 18^{\circ} 43^{\prime} 25.98^{\prime \prime} \mathrm{E}$ & Mud, algae & 15 & & 10 \\
\hline 15.09 .2018 & 1699 & HU & Dömös & $47^{\circ} 45^{\prime} 59.05^{\prime \prime} \mathrm{N} 18^{\circ} 55^{\prime} 02.18^{\prime \prime} \mathrm{E}$ & Mud & 14 & & 1 \\
\hline 28.08 .2018 & 1670 & $\mathrm{HU}$ & Göd 1 & $47^{\circ} 41^{\prime} 40.02^{\prime \prime} \mathrm{N} 19^{\circ} 07^{\prime} 45.00^{\prime \prime} \mathrm{E}$ & Sand, mud & 7 & & \\
\hline 28.08 .2018 & 1668 & $\mathrm{HU}$ & Göd 2 & $47^{\circ} 40^{\prime} 38.92^{\prime \prime} \mathrm{N} 19^{\circ} 07^{\prime} 29.08^{\prime \prime} \mathrm{E}$ & Clay, shells & 13 & & 1 \\
\hline 28.08 .2018 & 1655 & $\mathrm{HU}$ & Budapest, Újpest & $47^{\circ} 33^{\prime} 44.86^{\prime \prime} \mathrm{N} 19^{\circ} 04^{\prime} 15.45^{\prime \prime} \mathrm{E}$ & Sand, mud & 5 & & \\
\hline 28.08 .2018 & 1653 & $\mathrm{HU}$ & Budapest, Óbudai-sziget & $47^{\circ} 33^{\prime} 06.99^{\prime \prime} \mathrm{N} 19^{\circ} 02^{\prime} 53.90^{\prime \prime} \mathrm{E}$ & Sand, mud & 11 & & \\
\hline 29.08 .2018 & 1642 & HU & $\begin{array}{l}\text { Budapest, Ráckevei-Soroksári } \\
\text { Danube arm }\end{array}$ & $47^{\circ} 27^{\prime} 39.49^{\prime \prime} \mathrm{N} 19^{\circ} 04^{\prime} 20.90^{\prime \prime} \mathrm{E}$ & Rip-rap, mud & 5 & 1 & 10 \\
\hline 04.07 .2017 & 1642 & HU & Budapest, Lágymányosi-öböl & $47^{\circ} 27^{\prime} 33.90^{\prime \prime} \mathrm{N} 19^{\circ} 03^{\prime} 30.50^{\prime \prime} \mathrm{E}$ & Mud & 1 & 8 & \\
\hline 29.08 .2018 & 1631 & $\mathrm{HU}$ & Budapest, Nagytétény & $47^{\circ} 23^{\prime} 19.70^{\prime \prime} \mathrm{N} 18^{\circ} 59^{\prime} 32.16^{\prime \prime} \mathrm{E}$ & Sand, gravel & 5 & & \\
\hline 19.09.2018 & 1572 & $\mathrm{HU}$ & Dunavecse & $46^{\circ} 54^{\prime} 43.32^{\prime \prime} \mathrm{N} 18^{\circ} 57^{\prime} 53.50^{\prime \prime} \mathrm{E}$ & Sand, mud & 45 & & \\
\hline 19.09 .2018 & 1545 & $\mathrm{HU}$ & Harta & $46^{\circ} 41^{\prime} 33.58^{\prime \prime} \mathrm{N} 19^{\circ} 00^{\prime} 34.35^{\prime \prime} \mathrm{E}$ & Sand, gravel & 49 & & \\
\hline 19.09.2018 & 1507 & HU & Fajsz & $46^{\circ} 25^{\prime} 35.06^{\prime \prime} \mathrm{N} 18^{\circ} 54^{\prime} 22.90^{\prime \prime} \mathrm{E}$ & Mud & 20 & & \\
\hline 19.09.2018 & 1480 & HU & Baja & $46^{\circ} 11^{\prime} 36.28^{\prime \prime} \mathrm{N} 18^{\circ} 55^{\prime} 27.05^{\prime \prime} \mathrm{E}$ & Sand, mud & 54 & & \\
\hline 19.09.2018 & 1446 & HU & Mohács & $45^{\circ} 59^{\prime} 21.37^{\prime \prime} \mathrm{N} 18^{\circ} 41^{\prime} 52.03^{\prime \prime} \mathrm{E}$ & Mud, clay & 35 & & \\
\hline 19.09.2018 & 1425 & $\mathrm{HR}$ & Batina & $45^{\circ} 51^{\prime} 05.35^{\prime \prime} \mathrm{N} 18^{\circ} 51^{\prime} 16.09^{\prime \prime} \mathrm{E}$ & Mud, clay & 25 & & \\
\hline
\end{tabular}


unlikely in the range expansion reported here for the following reasons: (1) Based on the considerable research and monitoring activity on the river in recent decades (including several samples taken and/or identified by mysid specialists; e.g., Wittmann, 2002, 2007; Borza, 2007; Borza et al., 2015), it is not likely that the species has been overlooked in this river section for a long time. (2) The more than $700 \mathrm{~km}$-long river section upstream of the last reported range limit of the species (river km $~ 1200$ in 2013, Fig. 2; Borza et al., 2015) is blocked by two dams (at Freudenau and Gabčíkovo), and most of it can be characterized by relatively strong currents and coarse substrates (Fig. 2 in Borza et al., 2015), offering only small and isolated patches of suitable habitat for P. lacustris.

Rather, we assume that the species reached Vienna by jump dispersal (e.g., by ships) and colonized the intermediate river section rapidly by downstream drift, similar to all the other Ponto-Caspian peracarid species expanding in the river after the opening of the Main-Danube canal in 1992 (Borza et al., 2015). The establishment of the species in Vienna might be in connection with a previous record of a single specimen in 2004 (Wittmann, 2007). Such long lag-periods are often reported in terrestrial invasions where small "bridgehead" populations are more likely to be detected (Crooks and Soulé, 1999).

The species prefers fine sediments (sand, mud, or clay) with standing water or slow to moderate currents (Băcescu, 1954); therefore, the largest populations in the recently colonized river section might be formed in reservoirs. In fastflowing stretches with coarse sediments, the presence of the species might be restricted to isolated lentic patches (e.g., around groynes), whereas in slow-flowing sections of the river, it might inhabit the entire littoral zone. Revealing whether the species can also inhabit the offshore zone in such stretches would require further investigations.

The overall impact of the species is hard to predict. Stable isotope analyses have identified $P$. lacustris as omnivorous with larger specimens relying primarily on zooplankton (Lesutiene et al., 2007, 2008). The species also serves as an important food source for fish; however, long-term positive effects on fish production have not been proved (Arbačiauskas et al., 2010). Considerable negative consequences on the other mysids cannot be expected, since their habitat preferences (Borza et al., 2017) as well as their diets (Rothhaupt et al., 2014) are markedly different.

Based on the fact that all Ponto-Caspian peracarids that have crossed the Middle Danube have been able to continue their spread, P. lacustris can reasonably be expected to colonize the Upper Danube as well as other catchments in Western Europe in the future. As most of these waters can be characterized as a more-or-less continuous chain of reservoirs, the species might become an important member of their biota.

Borza et al. (2017) discussed the possibility of a new invasion wave consisting of psammo-pelophilous PontoCaspian peracarids in case substantial hydromorphological modifications (e.g., establishment of reservoirs, or deepening of the shipping channel) were carried out in the Middle Danube. We assume that $P$. lacustris is not the harbinger of a new wave but a late representative of the previous one. Its invasion success indicates that the large-scale spread of psammo-pelophilous species is possible even under the present conditions; however, drastic anthropogenic disturbances might considerably accelerate the process.

Acknowledgments. This work was supported by the NKFIH PD-115451 grant received by Á.E. from the Hungarian National Research, Development and Innovation Office and the GINOP 2.3.2-15-2016-00019 grant. Á.E. thanks the János Bolyai Research Scholarship of the Hungarian Academy of Sciences for supporting this study. The article benefitted from the comments of two anonymous referees and proofreading by Kendra Chilson.

\section{References}

Arbačiauskas K, Rakauskas V, Virbickas T. 2010. Initial and longterm consequences of attempts to improve fish-food resources in Lithuanian waters by introducing alien peracaridan species: a retrospective overview. J Appl Ichthyol 26: 28-37.

Arbačiauskas K, Višinskienė G, Smilgevičienė S, Rakauskas V. 2011. Non-indigenous macroinvertebrate species in Lithuanian fresh waters, Part 1: distributions, dispersal and future. Knowl Manag Aquat Ecosyst 402: 12.

Audzijonyte A, Baltrūnaitè L, Väinölä R, Arbačiauskas K. 2015. Migration and isolation during the turbulent Ponto-Caspian Pleistocene create high diversity in the crustacean Paramysis lacustris. Mol Ecol 24: 4537-4555.

Audzijonyte A, Baltrūnaitė L, Väinölä R, Arbačiauskas K. 2017. Human-mediated lineage admixture in an expanding Ponto-Caspian crustacean species Paramysis lacustris created a novel genetic stock that now occupies European waters. Biol Invasions 19: 2443-2457.

Băcescu M. 1954. Crustacea: Mysidacea, Editura Academiei Republicii Populare Romîne, Bucuresti, 126 p.

Bij de Vaate A, Jażdżewski K, Ketelaars HAM, Gollasch S, Van der Velde G. 2002. Geographi graphical patterns in range extension of Ponto-Caspian macroinvertebrate species in Europe. Can J Fish Aquat Sci 59: 1159-1174.

Borza P. 2007. Contribution to the macroinvertebrate fauna of the Hungarian Danube. III. Mysid shrimps (Crustacea: Mysidacea). Folia Hist Nat Mus Matraensis 31: 125-129.

Borza P, Boda P. 2013. Range expansion of Ponto-Caspian mysids (Mysida, Mysidae) in the River Tisza: first record of Paramysis lacustris (Czerniavsky, 1882) for Hungary. Crustaceana 86: 13161327.

Borza P, Csányi B, Huber T, Leitner P, Paunović M, Remund N, Szekeres J, Graf W. 2015. Longitudinal distributional patterns of Peracarida (Crustacea, Malacostraca) in the River Danube. Fundam Appl Limnol 187: 113-126.

Borza P, Huber T, Leitner P, Remund N, Graf W. 2017. Success factors and future prospects of Ponto-Caspian peracarid (Crustacea: Malacostraca) invasions: is "the worst over"? Biol Invasions 19: $1517-1532$.

Crooks JA, Soulé ME. 1999. Lag times in population explosions of invasive species: causes and implications. In: Sandlund OT, Schei PJ, Viken Å, eds. Invasive Species and Biodiversity Management. Dordrecht: Kluwer Academic Publishers, pp. 103-125.

Lesutienė J, Gorokhova E, Gasiūnaitė ZR, Razinkovas A. 2007. Isotopic evidence for zooplankton as an important food source for the mysid Paramysis lacustris in the Curonian Lagoon, the SouthEastern Baltic Sea. Estuar Coast Shelf Sci 73: 73-80.

Lesutienė J, Gorokhova E, Gasiūnaitė ZR, Razinkovas A. 2008. Role of mysid seasonal migrations in the organic matter transfer in the Curonian Lagoon, south-eastern Baltic Sea. Estuar Coast Shelf Sci 80: $225-234$. 
P. Borza et al.: Knowl. Manag. Aquat. Ecosyst. 2019, 420, 1

Rothhaupt K-O, Hanselmann AJ, Yohannes E. 2014. Niche differentiation between sympatric alien aquatic crustaceans: an isotopic evidence. Basic Appl Ecol 15: 453-463.

Wittmann KJ. 2002. Weiteres Vordringen pontokaspischer Mysidacea (Crustacea) in die mittlere und obere Donau: Erstnachweise von Katamysis warpachowskyi für Ungarn, die Slowakei und Österreich mit Notizen zur Biologie und zum ökologischen Gefährdungspotential. Lauterbornia 44: 49-63.
Wittmann KJ. 2007. Continued massive invasion of Mysidae in the Rhine and Danube river systems, with first records of the order Mysidacea (Crustacea: Malacostraca: Peracarida) for Switzerland. Rev Suisse Zool 114: 65-86.

Zettler ML. 2015. Kurze Notiz über die Ankunft von Echinogammarus trichiatus im Ostseegebiet und den Erstnachweis von Paramysis lacustris in Deutschland. Lauterbornia 79: $151-156$

Cite this article as: Borza P, Kovács K, György A, Török JK, Egri Á. 2019. The Ponto-Caspian mysid Paramysis lacustris (Czerniavsky, 1882) has colonized the Middle Danube. Knowl. Manag. Aquat. Ecosyst., 420, 1. 